\title{
Inwentarze, katalogi i spisy \\ w zbiorach rękopiśmiennych Muzeum Narodowego w Krakowie
}

biór rękopiśmienny Muzeum Narodowego w Krakowie liczący
około 2300 rękopisów to jeden z mniej znanych i mało docenia
nych zbiorów na terenie Krakowa. Swymi początkami sięga on roku 1879, kiedy Rada Miasta postanowiła uczcić jubileusz 50-lecia pisarstwa Józefa Ignacego Kraszewskiego.

Efektem obchodów jubileuszu wielkiego pisarza było powstanie Galerii Narodowej, która dała początek Muzeum Narodowemu w Krakowie. Nowopowstała instytucja poczęła gromadzić oprócz malarstwa, rzeźby i militariów, także rękopisy i stare druki. Powstanie swoje, zbiór przyszłego muzeum zawdzięcza przede wszystkim ofiarności różnych kolekcjonerów, którzy idąc w ślad za malarzem Henrykiem Siemiradzkim i jego Pochodniami Nerona obdarowali Muzeum gromadzonymi przez siebie starożytnościami i zabytkami piśmiennictwa polskiego. ${ }^{1}$

Przypadkowość darów - jak to czasami bywa - może badaczy zaskoczyć, tym bardziej, że zbiór ten jest otwarty, co jeszcze bardziej zwiększa jego atrakcyjność. Niewątpliwe główną przyczyną nieznajomości, a tym samym i niedoceniania tej kolekcji rękopiśmiennej, był brak naukowych jej opracowań. Co rusz poszczególne rękopisy cytowane są w pracach historyków, historyków sztuki i literatury. Jednak brak naukowego ich wykorzystania, nie jest zapewne adekwatny do ich wartości historycznej i muzealnej. W wyniku podstawowej działalności Muzeum Narodowego jakim jest wystawiennictwo, można było je oglądać na różnych wystawach, zawsze jednak przy okazji eksponowania innych obiektów muzealnych.

Cennym wyjątkiem dotyczącym opracowań naukowych kolekcji rękopiśmiennej jest Katalog dokumentów pergaminowych opracowany przez kustosza Biblioteki Czartoryskich Janinę Tomaszewicz w 1991 roku. Najmniejsza zatem część tego zbioru, ale jedna z najcenniejszych otrzymała jako pierwsza swój naukowy katalog. ${ }^{2}$

Z Badań Nad Polskimi Księgozbioram Historycznymi

t. 21, Warszawa 2003. 
Zbiór rękopisów Muzeum znany jest badaczom jedynie z inwentarza przygotowanego skrótowo $i$ jakby w pośpiechu przez Matyldę z Sapiehów Osterwę w latach 50 -tych, a w miarę powiększania i rozrastania się kolekcji, także $m$. in. przez piszącego te słowa.

Pierwsza, i jak dotąd najlepszą historię tego zbioru opracował dr Adam Homecki, jego kustosz od początku lat 60 ., któremu podlegał, przechowywany w jedym gmachu z rękopisami Biblioteki Czartoryskich. W miarę katalogowania zespołów rękopisów lub pojedynczych jednostek będą one opisywane także od strony ich historii i proweniencji, na razie, musi wystarczyć badaczom opracowanie dr A. Homeckiego. ${ }^{3}$ Prowadzone od dwóch lat bardzo intensywne prace katalogowe nad tym zbiorem rokują nadzieję, że otrzyma on niebawem pierwsze tomy naukowych opracowań.

Celem niniejszych rozważań jest spojrzenie na kolekcję rękopisów Muzeum Narodowego nie od strony jej historii, czy opracowania - choć w pewnym sensie je uwzględni - ale zwrócenie uwagi badaczy na zbiór, który kryje w sobie cenne źródła do dziejów książki i bibliotek od XVIII do początku XX wieku.

Rozszerzenie bazy źródłowej bibliologii polskiej to również „zmuszenie” badaczy do poszerzenia bazy archiwalnej i skierowanie ich uwagi na zasób archiwów i bibliotek nie tylko polskich, ale i krajów ościennych, które kryją bogactwo materiału źródłowego. ${ }^{4}$

Postulaty badawcze w tym względzie zgłaszane były wielokrotnie od lat 60-tych. Poświęcano im kolejne zeszyty Studiów o Ksiqżce ${ }^{5}$, czy sesje naukowe historyków książki i bibliologów. ${ }^{6}$ Głównym celem tych rozważań i spotkań było przejście od etapu stwierdzeń i postulatów do działań w zakresie poszukiwań źródeł archiwalnych nad dziejami książki, a następnie publikowanie konkretnych efektów kwerend archiwalnych.

Badania ostatnich 20 lat dowiodły, że etap wstępny historycy książki mają już za sobą. Niemałą rolę odegrało w tym względzie utworzenie Pracowni Księgozbiorów Historycznych w Bibliotece Narodowej i poszczególne tomy serii Z Badań nad Polskimi Ksiegozbiorami Historycznymi. ${ }^{7} \mathrm{Ol}-$ brzymie znaczenie miało także utworzenie Biura Pełnomocnika Rządu do Spraw Polskiego Dziedzictwa Kulturalnego za Granicą, którego pracownicy sami prowadzą badania nad historią księgozbiorów na wschodnich terenach dawnej Rzeczypospolitej i patronowali pracom nad wykazem strat bibliotek polskich na początku lat 90., rozprowadzając do poszczególnych bibliotek polskich specjalnie opracowane w tym celu ankiety. ${ }^{8}$ 
Nikt już nie ma wątpliwości, że publikacja źródeł do historii książki i bibliotek stanowi punkt wyjścia do badań monograficznych, biograficznych, publikacji słownikowych i encyklopedycznych. Najcenniejsze wśród tego typu źródeł są oczywiście katalogi i inwentarze poszczególnych zbiorów znajdujące się w bibliotekach i archiwach polskich. Wzorcowe publikacje zostały już dokonane.?

W dalszej kolejności czekają także na spenentrowanie źródła do dziejów książki rękopiśmiennej zawarte w sylwach staropolskich ${ }^{10}$, raptularzach, pamiętnikach, instrukcjach, nawet ekonomicznych, inwentarzach gospodarczych, księgach rachunkowych (np. klasztornych), testamentach staropolskich $^{11}$, także tych, zawartych w XIX-wiecznych księgach notarialnych ${ }^{12}$, by wspomnieć choć kilka rodzajów interesujących nas źródeł.

Poznanie wymienionego wyżej materiału archiwalnego pozwoli ujrzeć nowe pola badawcze, w tym także recepcję książki, jej społeczne oddziaływanie, na co zwróciła uwagę B. Bieńkowska przed kilkoma laty. ${ }^{13}$

Źródła o których tu mowa, dotycząjedynie bibliotek prywatnych-szlacheckich, magnackich, czy mieszczańskich. „Ziemią nieznaną” w tym względzie są w zasadzie księgozbiory instytucji kościelnych. Przed bibliologami stoją poszukiwania w tego typu archiwach, jednakże w tym momencie brak jest kompleksowych planów, nie mówiąc już o koncepcjach metodologicznych. Inicjatywy badawcze powinny w tej materii powstać być może, wokół Ośrodka Archiwów, Bibliotek i Muzeów Kościelnych przy KUL, a także wokół czasopism podejmujących tematykę historii Kościoła w poszczególnych diecezjach polskich.

Po tych kilku uwagach wstępnych, które w tym miejscu wydały się nieodzowne, pragniemy zwrócić uwagę na kilkadziesiąt, bardzo ciekawych i istotnych - jak się wydaje - źródeł archiwalnych do dziejów książki i bibliotek. Ich różnorodność zależna jest, jak wspomniano na wstępie od przypadku, który odegrał dużą rolę w gromadzeniu kolekcji rękopiśmennej Muzeum Narodowego w Krakowie, a zwiazany był także z zainteresowaniami ofiarodawców i kolekcjonerów.

Największą część źródeł stanowią inwentarze i katalogi ksiąg, w większości związane z bibliotekami Chodkiewiczów w: Młynowie, Czarnobylu, Konojadzie, Warszawie i Turzcu od początku lat 40. XVIII wieku do II połowy XIX wieku. Zbiór Chodkiewiczów ofiarowany został do Muzeum Narodowego w Krakowie w dwóch partiach - w 1919 i w 1936 roku. Nieszczęśliwie stało się, że zbiór ten rozdzielono w 1951 roku w ramach akcji przenoszenia rękopisów archiwalnych z bibliotek i muzeów do sieci archiwów pań- 
stwowych, w wyniku czego druga część kolekcji znalazła się w Wojewódzkim Archiwum Państwowym w Krakowie. Do Muzeum Narodowego trafiły głównie rękopisy biblioteczne, dyplomy pergaminowe i część akt gospodarczych. ${ }^{14}$

Z rodziną Chodkiewiczów spokrewnieni byli Sapiehowie z Kodnia, a inwentarze prezentowane niżej dotyczą głównie biblioteki Jana Fryderyka Sapiehy kanclerza wielkiego litewskiego (+1751 r.). Koneksjami rodzinnymi z Chodkiewiczami związany był także Józef Rzewuski starosta drohobycki, który sprzedał swoją bibliotekę Aleksandrowi Chodkiewiczowi na mocy tranzakcji w 1806 roku.

Kilka inwentarzy dotyczy różnych zbiorów magnackich i szlacheckich - Tekli Róży Wiśniowieckiej (+1747 r.), Branickich w Białymstoku, Jana Ansgarego Czapskiego wojewodzica pomorskiego oraz innych: Piotra Umińskiego w Warszawie, Gustawa Olizara, Henryka Siemiradzkiego, Stanisława Starzeńskiego z Ostrowa, Józefa Reitzenheima, Antoniego Urbanowskiego z Horodźca.

Osobną grupę stanowią katalogi i inwentarze bibliotek klasztornych: bernardynek w Słonimiu i Brześciu Litewskim, paulinów na Jasnej Górze, marianów w Puszczy Korabiewskiej (Mariańskiej).

Wśród innego rodzaju bibliotek wspomnieć wypada spisy książek Towarzystwa Numizmatycznego w Krakowie i biblioteki jednego z teatrów warszawskich.

W opisach inwentarzy, katalogów i innych źródeł przyjęto kryterium chronologiczne. Opis otwiera numer katalogowy opracowania i tytuł oryginalny lub nadany przez opracowującego spis. Po nim następuje sygnatura rękopisu z Inwentarza rękopisów Muzeum Narodowego, opis zewnętrzny z podaniem języka, datacji, wymiarów, liczby stron, oprawy. Następnie umieszczono informacje na temat zawartości inwentarza lub katalogu z wyszczególnieniem działów, jeśli takowe występują. Jak zatem wynika z podanych informacji, noty opisowe wzorowane są w zasadzie na przyjętych przez W. Jabłońską w cytownym wyżej artykule dotyczącym inwentarzy i katalogów Biblioteki Zakładu Narodowego im. Ossolińskich.

Różnorodność opisywanych katalogów i inwentarzy nastręczało pewną trudność w ich opisie, stąd korzystający z opracowania natrafić może na pewną ułomność spowodowaną niedokładnością lub skrótowością informacji. Opracowujący zdaje sobie sprawę, że poniższy wykaz służyć ma do dalszych studiów nad opracowaniem księgozbioru i dziejów danej biblioteki. 


\section{Inwentarz Biblioteki Chodkiewiczowów w [Mhynowie?].}

$817 / 1$ Rjęz $1741,33.5 \times 22.5 \mathrm{~cm}$. Bez opr. Luźne. S. 700. Oryg. B. zniszcz.

Spis zawiera 2100 dzieł w porządku alfabetycznym od A-Z s. 1-543; „Table alphabetique des auteurs" od A-Z s. 553-602; Wykaz skrótów użytych w inwentarzu s. 616; „Catalogue par ordre des Numero” od 1-2100 s. 617-696, z uwagami na s. 699 odnośnie niektórych sygnatur.

2. Katalog xiag Biblioteki Kodeńskiey Jaśnie Wielmożnego [...] Jana Fryderyka hrabi na Kodniu, Kopylach, Dorohostaiach y Czarnobylu Sapiehy kanclerza W. X. Litt., brześciańskiego [...] starosty [...] lacin̈skich, polskich, francuskich, niemieckich, wioskich, spisany die Ima may Anno 1744

818 Pol., łac. 1744. 34.5 x 20.5 cm. S. 324. Opr. płsk. Oryg. Katalog zawiera spisy dzieł w ramach poszczególnych języków według alfabetu: s. 3-122 „Eacińskie”; s. 123-208 ,Xięgi polskie 1744 [r.f”; s. 209276 oraz s. 324 „Xięgi francuskie [...] spisane A[nn]o 1744 die 2 may”; s. 277-299 „Xięgi niemieckie 1744"; s. 301-322 „Xięgi wloskie 1744"

3. Spis ksiag pozostałych po Michale Serwacym Wiśniowieckim i Tekli Róży z Radziwillów w 1745 roku.

865 Pol., łac. ok. 1810. 34.5 x 22 cm. S. 240. Opr. pap. Wypisy z ksiąg grodzkich krzemienieckich dotyczące sukcesji po hetmanie w. lit. Wiśniowieckim (+ 1744 r.) i jego żonie Tekli (+ 1747 r.). Na s. 228-230 w rękopisie znajduje się testament Tekli Wiśniowieckiej, który wyszczególnia jedynie liczbowo książki według kryterium językowego pod każdą literą alfabetu. W rezultacie na s. 228-230 testament zawiera ksiąg: łacińskich 1094; francuskich 1475; polskich 274. Ponadto na s. 230 podano liczbowo „księgi z Litwy przywiezione”: francuskich 75, polskich 79, łacińskich 82. Załączono informację, że spis biblioteki znajduje się u niejakiego Walentego Tormana burgrabiego zamku w Wiśniowcu.

4. Spis ksiag rękopismiennych i drukowanych znajdujacych się w archiwum Jana Fryderyka Sapiehy w Kodniu w 1758 roku.

851/3 Pol. $1758-1779$ r. 33.5 x 20 cm. S. nlb. $8+802+$ nlb. 2. Bez opr.

"Sprawy na hrabstwo Kodeńskie w w[oie]w[ó]dztwie Brzeskim leżace Anno 1758 die 15 Januarij". Sumariusz dokumentów dotyczących hrabstwa za lata 1475-1779. 
Na s. 761-766 zamieszczono „Regestr xiqg [i] manuskryptów w różnych oprawach y tomach nayduiacych się", który wylicza: 28 rękopisów, w większości miscellaneów staropolskich z XVIII wieku związanych z Sapiehami, w tym katalog dzieł łacińskich biblioteki kodeńskiej z 1749 roku i katalog ksiag niemieckich tej biblioteki z tego samego roku oraz indeks ksiąg biblioteki z 1736 roku; 14 druków, głównie z XVIII wieku, w tym: herbarze, konstytucje sejmowe, dzieła filozoficzne, religijne, literackie (Poezje E. Drużbackiej i Don Kichot Cervantesa).

5. Catalogus librorum Domini Professoris Philosophiae Martini Nicuta z $17 \times 1766$ roku.

$810 / 3$ Łac., niem. 1766 r. 20.5 x 18 cm. S. 10. Oryg. pisany ręką właściciela biblioteki. Poszyt.

Katalog zawiera alfabetyczny wykaz druków numerowanych w obrębie danej litery s. 3-7. Ogólna liczba druków wynosi 195. Brak wykazu w obrębie liter H-M. Na s. 9-10 zamieszczono „Manuscripta” w ilości 33 tytułów $\mathrm{z}$ różnych dziedzin, $w$ większości z matematyki.

Spis uwierzytelnił swym podpisem J. A. Treppenhauser.

Bibliografia: PSB T. XXIII Wrocław-Warszawa-Kraków-Gdańśk 1978 s. $127-128$.

6. Spis ogólny ksiażek w palacu w Dobrzyniewie w starostwie knyszyńskim w 1766 roku. Oryg.

110 Pol. 1766 r. $34.5 \times 20.5$ cm. S. 140, zapis. od 7-116. Opr. sk. „Inwentarz folwarków do starostwa knyszyńskiego należacych z posessyi [...] [Jana Klemensa Branickiego] hetmana wielkiego koronnego przez [Pawla Tadeusza Czapskiego] wojewodzica pomorskiego, generala majora wojsk koronnych, starostę knyszyńskiego [...]" 30 VI 1766 r. Inwentarz zawiera na s. 13-14 krótki opis sprzętów biblioteki pałacowej, na s. 13 podaje ogólną liczbę książek: ,[...] xiq̨żek $w$ szafach górnych, $w$ francuskiey oprawie ulożonych sześśset pięćdziesiat, item xiqżek brakowanych w różnej oprawie osiemdziesiąt pięc, te $w$ dolnych szafach zlożone, do sztychowania liter w pudelku stępliki żelazne, xięga duża w pokrowcu z samemi mappami, xiqżka procedencyi Domu saskiego y krolów wszystkich alias elektorów saskich, item kopersztychów ośm, jeden króla Augusta trzeciego, resza różnych architektur [...]". 
Ponadto na s. 111 zamieszczono „Decess różnych rzeczy tudzież stadniny przy spisaniu teraźnieyszym wedlug tradycyi 1749. tak w pałacu Dobrzyniewskim iako y w różnych mieyscach [...], w którym informacja: W stayni xiażek niemieckich dwie desideratur; ponieważ bylo wyrzuconych z Biblioteki piętnaście, a teraz tylko znayduie się trzynaście, te xiażki dyssydenckie byty".

7. Spis biblioteki palacu Branickich w Bialymstoku. [II pol. XVIII w.].

106 Pol. 1772 r. 37 x 24 cm. S. 1234. Opr. sk. Oryg.

„Inwentarz dóbr wszystkich [...] Branickich" zakończony 3 X 1772 r. Na s. 1224-1228 zawiera 91 pozycji tytułowych oraz stan liczbowy map (szt. 51), abrysów i planów (szt. 261), kopersztychów (szt. 103), globusów (szt. 9). Na s. 1228-1229 dopisano informację, że do wykazu należy dodać 51 dzieł znajdujących się w pokojach pałacowych. Inwentarz podpisany i opieczętowany przez Izabelę Branicką kasztelanową krakowską i hetmanową w. kor. żonę Jana Klemensa Branickiego.

8. Spis ogólny biblioteki [w Turzcu lub Czarnobylu] Jana Mikolaja hrabi Chodkiewicza starosty generalnego żmudzkiego podpisany przez wdowe Ludwike z Rzewuskich Chodkiewiczowa w 1781 roku.

$825 / 3$ Pol. 1781 r. 32.5 x 20.5 cm. K. ochr. $1+$ s. 48 . Opr. płsk. Oryg. „Regestr rzeczy muchomych y niemuchomych po śmierci [...] Jana Mikolaia Xawerego [...] hrabi Chodkiewicza [...] pozostatych, przez mnie Ludowikę z Rzewuskich hrabinę Chodkiewiczową starościnę księstwa żmuydzkiego pozostala malżqka [!] wdowa niżej wlasnq ręka podpisana [...]" $1781 \mathrm{r}$.

Na s. 4 podano liczbowy wykaz ,Biblioteka

xiqg polskich pod różnymi tytulami 190

xiqg francuskich 588

xiag lacińskich 46

xiag niemieckich 104

xiag moskiewskich 8 "

oraz na s. 34 „Ornamenta palacu Czarnobylskiego [...]”, na s. 35 ,mapp generalnych trzy"; natomiast na s. 40-41 „Summaruysz fascykulów dokumentów w Archiwum Czarnobylskim znayduiqcych się", gdzie wykazano archiwalia rodowe, dokumenty gospodarcze, sumariusze archiwum - 14 rękopisów i 13 „xiqg drukowanych do manuskryptów należqcych". Ksiega oblatowana w grodzie w Owruczu w $1781 \mathrm{r}$. 
9. Różne notaty dotyczqce ksiqżek spisane przez Józefa Rzewuskiego starostę drohobyckiego w jego Sztambuchu.

758/7 Pol., franc. 1781 r. 18.5 x 11 cm. S. 105. Opr. sk. Współczesna. Wśróđ różnych zapisek osobistych, gospodarczych, refleksji z podróży znajdują się materiały dotyczące zainteresowań książką.

1. Notatki z podróży do Wiednia w $1781 \mathrm{r}$.

a/ informacje o cenach ksiażek s. 27.

b/ Wśród rzeczy kupionych w Wiedniu znajduje się "Kalendarzyk" szt. 2. s. 31 .

2. Adres introligatora Schultza w Marywilu k/Warszawy s. 28.

3. "Xiążki podróżne" spis 20 tytułów, s. 29.

4. „Xiqżki potrzebne”. Spis kilkunastu dzieł z XVII-XVIII w. S. 32-35.

5. „Xięgi w drogę z Podhorzec wzięte 20 Februarij [1780]" Następuje spis 11 dzieł w 14 woluminach s. 56.

6. "Xięgi kupione $w$ Wiedniu 1780 An[no]"

a/ ,in folio" 13 dzieł w 30 woluminach s. 57-58.

b/ ,in 8 maiori" 1 dzieło s. 58 .

c/ „,in quarto" 16 dzieł w 25 woluminach s. 59-60.

d/ ,in 8vo" 51 dzieł w 101 woluminach s. 61-67.

e/ „in 12mo" 12 dzieł w 22 woluminach s. 68-69.

7. Na s. 46 notatka: „Xiqżek kupionych w Wiedniu R. 1781" jest woluminów in folio 35 , in quarto 40 , in octavo 73 , in duodecimo 53, razem 201 woluminów.dzieł. Na s. 50-55 notatka podająca ilość 78 dzieł i w 201 woluminach.

8. „Xiqżki kupione $w$ Wiedniu” bd. , 3 dzieła w 4 woluminach s. 70 .

9. „Xiqżki kupione we Lwowie” bd. 2 dzieła w 4 woluminach s. 71.

10. „Xiqżki kupione w Warszawie R. 1780” 1 dzieło s. 72.

11. „Xiegi potrzebne” 25 tytułów w 30 woluminach bd. s.. 83-89. Spis inny niż na s. 32-35.

12. Notatka: „Die 258 b [ris] $1780 w$ Wiedniu w pace maley zapakowanych ksiqżek iest sztuk 7: in folio 1, in quarto 3, in octavo 3", dalej ,Xięgasz [!] nayslynnieyszy w Wiedniu nazywa się Rodolphe Graffer".

10. Różne spisy ksiag z Biblioteki Chodkiewiczów.

817/2b Rjęz. II pol. XVIIIw. (w tym 1788 r.). 33.5 x 19.5 cm. Poszyt. S. 1-26 (Stara foliacja k. 153-163 + 1 k. luźna. Oryg.

1. „1788 le 1 Avril. Les Livres achetés à Varsovie chez Mr Posen”. Spis zawiera tytuły 4 dzieł w 7 woluminach s. 2 . 
2. "Les livres achetés à Varsovie le 2 Juin an[no] 1788". Spis zawiera 13 tytułów dzieł w 67 woluminach s. 2.

a/ "Cette [!] livre acheté à Możejków ce 30 Auguste [1788]". 1 tytul w 1 woluminie

b/ „Les livres achetés à Swistocz le 4 Septembre Anne 1788". Zawiera 2 dzieła w 12 woluminach s. 3 .

3. „Les livres achetés à Zelva le 22 auguste 1788 An[no]”. Spis zawiera 16 tytułów dzieł s. 2-3.

4. „Regestr xiag polskich w Warszawie kupionych" [1788]. Spis zawiera 8 tytułów w 10 woluminach.

5. "Catalogue des livres achetés à Czarnobyl appartenant en propre a S. E. [?] Anne 1788 de 13 Décembre à Turzec". Wykaz zawiera 39 tytułów z podaniem ilości tomów s. 7-8.

6. „Les livres achetés à Varsovie 1789”. Spis zawiera 29 tytułów w 70 woluminach s. 8-10.

7. „Les livres achetés par Mr Holubeski à Varsovie 1789 de 14 August”. Zawiera 39 tytułów w 106 woluminach s. 10-11 oraz spis ksiażek kupionych w Warszawie [w 1789 r.] złożony z 50 tytułów w 154 woluminach s. 11-13; ponadto spis ksiazżek kupionych u Józefa Lexa w Warszawie - 71 tytułów w 147 woluminach s. 13-14, 19-20.

8. Spis 6 tytułów dzieł w 47 woluminach kupionych u J. Lexa w Warszawie 6 VII 1790 s. $13,15$.

9. Spis 5 książek w 14 woluminach kupionych w Warszawie 4 XI $1790 \mathrm{r}$. s. 20 .

10. Spis 5 książęk w 17 woluminach kupionych w Warszawie 20 XI 1790 r. s. 20.

11. „Nowoprzybyle [ksiażki] 1792 m.[iesia]ca januarij 17 dnia”. Spis zawiera 28 tytułów w 64 woluminach s. 20-21.

12. "Les livres achetés à Vien[ne]” [ok. 1790 r.] . Wykaz zawiera 24 tytuty dzieł w 38 woluminach s. 23-24.

13. „Extracte du Catalogue des livres, qui se trouvent dans la libraire de Trattnern [à Vienne]". Zawiera 17 tytułów dzieł, bd. s. 25-26.

11. Spis ksiażek kupionych do biblioteki Józefa Rzewuskiego starosty drohobyckiego od Michata Wielhorskiego 20 III $1792 \mathrm{r}$.

817/2a-1 Pol, franc., łac. 1792 r. 38 x 24 cm. Poszyt. S. 20. Bez opr. Oryg. Pisany przez J. Rzewuskiego.

Spis zawiera 98 dzieł drukowanych od XVI-XVIII wieku z podaniem sygna- 
tury, ilościa woluminów i ceną. Na s. 19 pokwitowanie odbioru pieniędzy przez Wielhorskiego.

12. Spis ksiqżek kupionych do biblioteki Józefa Rzewuskiego starosty drohobyckiego od Michata Wielhorskiego 12 IV 1793 r:

817/2a-2 Pol., franc. 1793 r. 38 x 24 cm. Poszyt. S. 8. Bez opr. Oryg. Pisany przez J. Rzewuskiego.

Spis zawiera 67 dziel drukowanych od XVII-XVIII w. z podaniem ich sygnatur w bibliotece Rzewuskiego, ilością woluminów i ceną. Na s. 6 załączono pokwitowanie odbioru pieniędzy przez Wielhorskiego.

13. Spis ksiażek z biblioteki Józefa Rzewuskiego starosty drohobyckiego $z$ końca XVIII w.

817/2a-3 Pol., łac., franc. Koniec XVIII w. 22.5 x 18 cm. Luźne. S. 8. Oryg.

Spis zawiera 70 tytułów dzieł historycznych, głównie autorów starożytnych (greckich, rzymskich, bizantyjskich) i literatury starożytnej (3 tytuły) pisane własna reka właściciela biblioteki.

14. Spis ksiqżek kupionych do biblioteki Józefa Rzewuskiego starosty drohobyckiego od Michata Wielhorskiego 18 II 1795 r.

817/2a-4 Pol., franc. 1795 r. 37 x 23.5 cm. Luźne bez opr. S.4. Oryg. Spis zawiera 14 tytułów dzieł polskich, francuskich i łacińskich w 31 woluminach od XVI do XVIII wieku. Na s. 2 pokwitowanie odbioru pieniędzy przez M. Wielhorskiego.

15. Rachunki za książki wystawiane dla rodziny Chodkiewiczów przez różnych księgarzy m. in. M. Grolla, Karola B. Pfaffa i NN z lat 1778-1779 oraz Karola Wilda.

820/5a-e Pol., niem. II pol. XVIII w. Luźne.

16. Regestr ksiazzek rozpożyczonych z Biblioteki J. W. Hrabiny [Ludwiki] Chodkiewiczowej starościny żmudzkiej od dnia 21 9bris 1800 roku w Mtynowie.

817/2c Pol., 1800 r. 34 x 21 cm. Luźne, s. 6. Oryg. Regestr zawiera jedynie dwa nazwiska wypożyczających. 
17. Regiestr rzeczy kościelnych spisany w roku 1802 dnia 1 augusta za przelożęństwa! w Bogu [...] Serafiny Seyffardówny, a zakrystyaństwa siostry Delfiny Śliżewiczówny [w klasztorze SS. Benedyktynek w Slonimiu].

880b Pol., 1802 r. Opr. płsk. z rzemykami. S. 20.

Na s. 5 znajduje się wykaz ,Xięgi” który podaje liczbowo: mszałów w srebro oprawnych 2, mszałów oprawnych, mszalików żałobnych 3, Agenda duża 1, agendek małych 3, ksiażki brackie - Niepokalanego Poczęcia N. M. Panny 1, Najświętszej Panny Szkaplerznej 1, Opatrzności Boskiej 1, wszystkich 3, Ewangelijka 1.

18. Spis rękopisów sporzadzonych własnoręcznie z różnych dziet obcych przez hr: Stanislawa Starzeńskiego w Ostrowie w 1809-1810 r:

510/3 Pol., niem. 1809 r. 24 x 19 cm. Poszyt bez opr. S. 8. Zawiera 19 miscellaneów powstałych na skutek odpisów z dzieł bibliotecznych w wyżej wymienionych latach.

19. Spis ogólny ksiażek w bibliotece Aleksandra Chodkiewicza w Pekalowie w $1810 \mathrm{r}$.

$817 / 4$ a/ Pol. 1810. $22.5 \times 17.5 \mathrm{~cm}$. S. 16. Oryg.

b/ Pol. 1810. $24.5 \times 19.5 \mathrm{~cm}$. S. 12 . Oryg.

„Regestr zapakowanych obrazów i biblioteki Pekalowskiej iako i machin fizycznych [...] [Aleksandra] Chodkiewicza przez Józefa Kerna. 1810".

Zawiera wykaz książek w poszczególnych pakach:

Paka 7: książki teologiczne 219 szt.

Paka 8: ksiązki teologiczne 236 szt.

Paka 9: książki [botaniczne] 60 szt.

Paka 10: dykcjonarzów 24 szt.

książek dotyczących prawodawstwa 2 szt.

Paka 11: dykcjonarzów 11 szt.

encyklopedycznych 37 szt.

Paka 12: ciag dalszy książek prawniczych i lekarskich 128 szt.

Paka 14: ciąg dalszy książek lekarskich 294 szt.

Paka 16: 189 książek

Paka 17: 136 ksiażek

Paka 18: książek politycznych 214 szt.

Paka 19: 325 książek

Paka 20: książki z fizyki, botaniki, ekonomii, mineralogii 384 szt.

Paka 21: kontynuacja książek botanicznych, handlowych i „wojażów Napoleona" 317 szt. 
Paka 22: książki matematyczne, podróżnicze i geograficzne 317 szt.

Paka 23: książki geograficzne i z historii powszechnej 435 szt.

Paka 24: ciag dalszy 567 szt.

Paka 25: rożnych 328 szt.

Paka 26: książki dotyczące historii i „początek umiejętności” oraz katalog alfabetyczny 980 szt.

Paka 27: ciąg dalszy „umiejętności” oraz dzieła mieszane 444 szt.

Paka 28: książki mieszane 1380 szt. oraz gazety warszawskie i gazety francuskie bez podania ilości.

R a z e m. wszystkich książek: 4134 sztuki.

20. Ksiqżki pożyczane. Ksiqżka wypożyczeń biblioteki Chodkiewiczów [w Miynowie] w latach 1815-1818.

817/5 Rjęz. 1815-1818. 35,5 x 22 cm. Poszyt. S. 16. Zniszcz.

Księga wyszczególnia datę wypożyczenia, tytuł dzieła, dział, poddział, ilość dzieł i tomów, nazwisko wypożyczającego wpisywane własnoręcznie, rubrykę z datą zwrotu.

21. Wykaz ksiażek starych ..., klasztoru bernardynek $w$ Stonimiu $1816 r$ :

822 Pol., 1816. $34 \times 21.5 \mathrm{~cm}$. Poszyt. Opr. pap. S. 16. Oryg. i kopia „Akt wizyty Jeneralney Slonimskiego WW. Panien Bernardynek klasztoru" 2 VII 1816 r. Zawiera na s. 7 opis stanu biblioteki klasztornej. Znajduje sie tam 10 brewiarzy łacińskich, 1 martyrologium łacińskie, 1 żywot świetych, 1 kronika zakonna polska, Rok bogomyślny z poczwórnymi na każdy dzien medytacyami ..., ks. Gaudentego Pikulskiego, 1 Kazania Piotra Skargi b. m. i r. wydania, Tomasza a Kempis, O naśladowaniu Chrystusa, nieznanych autorów dwa dzieła: Pochodnia adwentowa i Nauki o pokorze, 1 egzemplarz Katechizmu zakonnego oraz Rekolekcye duchowne na ośm dni rozłożone..., ks. Franciszka Przyłęckiego, w 10 egzemplarzach.

22. Summariusz, w którym kathalogi [!] xiqżek w Bibliotece Kodeńskiej [...] Jana Fryderyka Sapiehy [...] znayduiacych sie, iako tez Regestra, notaty do Bibliotyki [!] [...] Ludwiki hrabiny Chodkiewiczowej należace, Regestr sreber [...] Jana Mikolaja [...] Chodkiewicza [...], opisanie palacu Mlynowskiego [...], palacu Dubieńskiego [...], regestra muchomości [...] Ludwiki hrabiny Chodkiewiczowej w Czarnobylu pozostatych, spisane [...] r: 1817 [...] w Mtynowie" dotyczacych lat 1738-1816. Sumariusz spisany przez Stanislawa Roguskiego podsędka dobrzynieckiego 21 XII 1817. 
817/6 Pol., 1817. $32.5 \times 21.5$ cm. Opr. płsk. S. 56. Oryg.

Summaryusz wiadomości w części o bibliotece. Regestra różnych ruchomości...

N 1-o Biblioteki Sapieżyńskiey alfabetycznie sporzadzony [...] Regestr, bd. s. 3.

N2-o Roku 1738 I januarij xiqżek w bibliotece [...] Jana Fryderyka Sapiehy [...] Kodeńskiey [...] Kathalog s. 3

N 3-o Roku 1744 die 1 maia xiag Biblioteki Kodeńskiey [...] Jana Fryderyka Sapiehy [...] tacinskich, polskich, francuskich, niemieckich, wloskich spisany [...] alfabetyczny kathalog s. 3.

N 4-o Roku 1750 xiqżek w Bibliotece [...] Jana Fryderyka Sapiehy [...] Kathalog s. 3.

N 5-o Przystanych xiag z Warszawy od [...] Lexa do Biblioteki [...] Ludwiki hrabiny Chodkiewiczowej spisany Regestr s. 3.

N 6-o Roku 1801 die 22 Februarij kopersztychów, portretów, xiqziek z palacu możaykowskiego wziętych do Mlynowa spisany Regestr s. 4.

N 7-o [...] dla wiadomości [...] Ludwiki Chodkiewiczowej róznych dziel $i$ autorów onych $w$ osobnych regestrach zebranych [...] Notaty s. 4.

N 8-o Róznych dat z bez dat xiqżek wydawanych z Biblioteki [...] Ludwiki [...] Chodkiewiczowej do oprawy [...] Regestra s. 4.

23. Inwentarz biblioteki OO. Paulinów na Jasnej Górze w Częstochowie sporzqdzony w roku 1818. [Tytul nadany przez ks. Marcinkowskiego pod nim podpis oryg.]

457 Pol., 1818. $39.5 \times 24 \mathrm{~cm}$. Bez opr. 24 poszyty. S. 396. Oryg. Inwentarz zawiera dzieła wedhug 17 działów z podaniem numeracji, w ramach działów według alfabetu; pisany na specjalnie do tego przeznaczonych formularzach drukowanych zarubrykowanych, z podaniem formatów i liczby tomów. Pod inwentarzem widnieje podpis: „Xiadz Eugeni Lochowski prowincjal XX Paulinów" i pieczęć oryg. tuszowa.

24. Cathalogue [!] de la Bibliothéque de Kozackie année 1826 Rzewuskich pisany reką Ludwiki Chodkiewiczowej.

824 Franc. 1826. $35.5 \times 22.5$ cm. Poszyt. S. 44.

Zawiera spis książek według działów w poszczególnych szafach, z podaniem wartości w działach, ilości woluminów. Wartość biblioteki w 1829 roku wynosiła 16053 złotych. 
25. Akta sqdowe dotyczqce biblioteki Aleksandra Chodkiewicza 18261832.

819 Pol. 1826-1832. 37 x 21.5 cm. Luźne, k. 14. Szt. 5. Oryg. Dokumenty urzędowe dotyczące m. in. założenia biblioteki pod nr 1969 w Warszawie przez niejakiego Rembiszewskiego, bd.; pozew na rozprawę sądową w tej sprawie, 27 VI 1826, Warszawa; akt dotyczący urzędowych dozorców biblioteki i ruchomości, 1 IX 1832; akt dotyczący przeniesienia biblioteki do lokalu przy ul. Leszno 733 w Warszawie; „dalszy ciag dzialania mającego na celu ogólne przeprowadzenie biblioteki i innych nieruchomości [...]" 1 IX 1832, Warszawa.

26. [Inwentarz Biblioteki Warszawskiej hr. Aleksandra Chodkiewicza $1835 \mathrm{r}$.

819/2 Pol. 1835.32 .5 x $20.5 \mathrm{~cm}$. Poszyt. S. 64. Oryg.

Przegląd i rewizja biblioteki (i in. ruchomości Chodkiewicza) złożonych i zapieczętowanych w domu przy ul. Leszno nr 733 w Warszawie 11/23 VI - 19 VI/1 VII 1835. Spis obejmuje 90 pak z ogólną informacją jakie dzieła obejmuje dana paka i podaniem ilości woluminów. Ogółem w pakach znajduje się 17300 woluminów, co potwierdzone zostało podpisami taksatorów na s. 27 i podpisem komornika Jozafata Magnuszewskiego.

\section{Katalog Biblioteki Mtynowskiej w roku 1838 [spisany].}

821 Rjęz. 1838.35 x 22.5 cm. S. 84. Opr. płsk.

1. Zawiera spis dzieł drukowanych przechowywanych w VIII szafach, na parterze pałacu w Młynowie Chodkiewiczów oraz szafie na piętrze i tzw. szafie angielskiej zawierającej „Stare księgi”, według 24 działów, pisany w większości ręką Aleksandra Chodkiewicza s. 1-50.

2. Xiążki własne Mieczysława Chodkiewicza. S. 52-53, szt. 1-29. Co najmniej 6 kart wyrwano; Na s. 54-84 Spis xiążek własnych Mieczysława Chodkiewicza alfabetycznie ułożony pisany reką Aleksandra Chodkiewicza zawierający dzieła od XVII do XIX w.

\section{Inwentarz Biblioteki Aleksandra Chodkiewicza w $1840 \mathrm{r}$.}

819/3 Pol., 1840, 1890.34 x 21 cm. Fascykuł. S. 336. Kopia uwierzytelniona.

Inwentarz wykonano w domu nr 733 przy ul. Leszno w Warszawie należącym do sukcesorów Aleksandra Chodkiewicza (+1838).

a/ Dokument s. 9-316 zawiera dzieła ood 1-1842 oraz dopisane później nr 1843-1890, uwierzytelniony w 1890 r. pieczęcią. 
b/ Dokument s. 310, egzemplarz identyczny jak wyżej.

c/ Dokument s. 340, niekompletny, zawiera jedynie dzieła od nr 1-1869.

d/ Dokument stanowiący kopię powyższego s. 144, zawiera dzieła pod nr 456-1819 bez uwierzytelnienia.

29. [Inwentarz biblioteki śp. Barbary z Dembińskich 1-o v. Czackiej, 2-o v. Sedlmayerowej $1840 \mathrm{r}$.]

895 Pol. 1840. 37.5 x 23.5 cm. S. 200. Opr. płpł. Kopia współcz. nie uwierzytelniona.

Inwentarz spisał Sebastian Korytowski notariusz publiczny Wolnego Miasta Krakowa obejmując ruchomości i nieruchomości, w tym kosztowności, przedmioty użytkowe ułożony w XX rubruk (działów). Rubryka XVII obejmuje bibliotekę spisaną 7 VII 1840 r. W jej skład wchodzą wymienione z tytułów na s. 51-171:

1. Dzieła w języku francuskim poz. 1-1044

2. Dzieła w języku francuskim niekompletne poz. 1045-1079

3. Dykcjonarze poz. 1080-1114 z XVIII-XIX w.

4. Dzieła w języku łacińskim poz. 1115-1144 z XVII-XIX w.

5. Dzieła w języku włoskim poz. 1145-1172 z XVI-XIX w.

6. Dzieła w języku niemieckim poz. 1173-1278 z XVII-XIX w.

7. Dzieła w języku polskim poz. 1279-1366 z XVII-XIX w.

8. Dzieła w języku angielskim poz. 1367-1368 z XVIII w. i bez dat.

9. Dzieła w języku rosyjskim poz. 1369-1378 z XVIII w.

Wartość biblioteki podana na s. 170 wynosi 1960 złotych polskich i 5 groszy. Książki taksował Ambroży Grabowski w obecności Józefa Sedlmayera, kuratora Olearskiego, Wincentego Szpora, Bernarda Uszewskiego i Piotra Siemontowskiego. Można przypuszczać, że jakaś część książek, choć minimalna pochodziła $\mathrm{z}$ dawnej biblioteki Tadeusza Czackiego w Porycku, być może nie sprzedana Czartoryskim do Puław w 1818 roku. Por. Słownik pracowników ksiqżki polskiej, Warszawa-Łódź 1972 s. 135-136 oraz P. Sczaniecki, Zamek w Korzkwi i jego dziedzice, Kraków 1998.

30. Inwentarze ksiażek pochodzacych z dawnej biblioteki Aleksandra Chodkiewicza ok. $1840 \mathrm{r}$.

820/1 Pol., franc. Ok. 1840. Luźne.

1. Liste des ouvrages achetés à l'Enchere de la bibliothéque de feu M. le C[on]te [Alexandre] Chodkiewicz. Poszyt s. 1-12. Spis ręką Chodkiewicza, jego uwagami i z podaniem cen. 
2. Katalog ksiażek na licytacji kupionych [...] przez P. Aleksandra [Chodkiewicza] [...]. Poszyt s. 1-40. Obejmuje 557 tytułów dzieł, ilości tomów oraz cen wywoławczych.

3. Spis ksiazzek do [...] hr. Chodkiewicza należqcych, które w siedmiu pakach ułożone do Mlynowa wysłane przez Kijów dn. 9 marca/28 kwietnia $1844 \mathrm{r}$. Poszyt s. 1-28. Obejmuje ponad 500 tytułów dzieł z podaniem tomów i zawartości poszczególnych pak.

4. Spis dziet nabytych przez Aleksandra Chodkiewicza $w$ antykwariacie Lombarda. Poszyt s. 1 - $28+1$ k. doklejona przez Chodkiewicza o niedokładności informacji. Zawiera 566 dzieł.

5. Seconde partie de vente. Liste détaillée des ouvrages achetés par Mr Lombard pour Mrs Chiodkiewicz, 16 XI 1840, 7 II 1841. Poszyt s. 1-28. Podano nr katalogowy aukcji i cenę.

31. Spis papierów znajdująych się w komodzie [...] w Bibliotece Mtynowskiej 1844.

$820 / 3$ Pol. 1844.34 x 21.5 cm. K. 4.

Zawiera spis kilkudziesięciu plikówróżnych dokumentów od A - Z zawierających listy królów polskich, dokumenty do dziejów Polski, papiery sejmowe, dokumenty rodzin Chodkiewiczów i Sapiehow, czasopisma, dokumenty z lat 1776-1809, 1812 -1820 oraz osobiste dokumenty Aleksandra Chodkiewicza ułozone przez Karola Chodkiewicza.

32. Spis czasopism z biblioteki Aleksandra Chodkiewicza i inne papiery biblioteczne 1846-1850 r.

820/2 Franc. 1848. Luźne.

1. Rachunki dotyczace zakupow książek w antykwariatach Odessy, Warszawy, Drezna i Paryża, 1846-1850, szt. 6.

2. Katalog gazet $\mathrm{z}$ dawnej biblioteki A. Chodkiewicza sporządzony ok. połowy XIX w. Poszyt s. 1-12. Zawiera spisy tytułów gazet polskich, francuskich i niemieckich $\mathrm{z}$ podaniem roczników i tomów.

33. Spis rękopisów z dawnej biblioteki Aleksandra Chodkiewicza [przed pol. $X I X w$.$] .$

820/4 Pol., przed poł. XIX w. 23 x 19.5 cm. Fascykuł. K. 9.

Zawiera Katalog dziel w prozie. Rękopisma, wśród których znajdują się rękopisy staropolskie - dokumenty, korespondencja, literaria, varia. 
34. Regestr ksiażek do Biblioteki klasztoru [księży marianów w] Puszczy Korabiewskiej [Mariańskiej] należacych sporzqdzony w r[ok]u 1845.

12 Pol. $1845.36 \times 22.5 \mathrm{~cm}$. S. 60 + luźne dokumenty s. 1-14. Opr. płsk. Oryg.

Księga zawiera wykaz dzieł:

Ksiqżki lacińskie od A-W z podaniem autorów i tytułów, bez miejsc wydania wg numerów skaczących s. 1-14, 16, 57-60.

Ksiazki zbywajace bez numerów s. 5-16, 31, 56.

Ksiażki polskie wg układu alfabetycznego A-Z s. 18-19, 45-54.

Ksiażki w obcych językach nr 1-30 s. 30, 55.

Ksiqżki naukowe nr 1-13 s. 30-31, 55.

Na s. I-2 rewers ks. M. Komorowskiego na wypożyczone dwa dzieła w 1846 roku oraz na s. 31-32 rewizje biblioteki przeprowadzone w 1845 roku przez brata J. Naruszewicza jako wikariusza generalnego oraz 24 VIII 1853 roku przez tegoż sprawujacego funkcje prepozyta generalnego.

34. Spis ksiażek z biblioteki Henryka Siemiradzkiego w Rzymie spisany przez B. Siemiradzkiego, a ukończony 17 X 1894 roku.

1588 Pol. 1894. Dwa zeszyty. S. $25+48$ (pisany obustronnie). Opr. pap.

I. Poszyt. Zawiera spis książek w szafach znajdujących sie w poszczególnych pokojach (w pracowni, pokoju narożnym i przedpokoju) z informacjami: nr porządkowy, autor, tytuł, ilość woluminów. Razem 354 tytułów od 1-354. II. Poszyt. A/ Zawiera spis ksiażek w takim samym układzie jak wyżej od nr 355-1043.

B/ Paginacja od końca s. 1-5: Książki po śp. Wł[adysławie] hr Kulczyckim pisarzu i polityku emigracyjnym zamieszkałym w Rzymie. Spis obejmuje nr 1-102 w 182 woluminach, łącznie z czasopismami, które Siemiradzki kupił [?] od Kulczyckiego.

35. Spis biblioteki Gustawa Olizara w Korosteszowie.

823 Pol. ok. poł. XIX w. 25.5 x 20.5 cm. Poszyty s. 106 i s. 148. Opr. pap.

1. Katalog porzqdkiem alfabetu ulożony autorów, tlumaczów i kommentatorów, których dziela znayduiq się w Bibliotece Korosteszowskiej wraz z tychże dziel wskazaniem od A-Z z podaniem szafy, litery i numeru pod którym znajduje się dzieło. 
2. Katalog Biblioteki Korosteszowskiej porzqdkiem alfabetu utożony z podaniem numeru szafy, litery i dzieła oraz tomu. Katalog rózni się od powyższego. S. 1-148.

36. Spis książek pozostatych po Józefie Reitzenheimie postańcu, publicyście i kolekcjonerze (1809-1883).

186 Pol. II poł. XIX w. 33.5 x 21 cm. S. 36. Odbitka litograf. Opr. tekt.

Spis biblioteki Reitzenheima znany $\mathrm{z}$ wielu odbitek w różnych bibliotekach.

Dzieła polskie s. 1-7.

Dzieła francuskie s. 8-13.

Dzieła angielskie s. 14.

Dzieła włoskie, hiszpańskie i lacińskie s. 15.

Dzieta niemieckie s. 16-17.

Stowniki s. 18.

Mapy $i$ atlasy s. 18.

Listy pisane do śp. Reitzenheima przez..., s. 19-26.

Obrazy i plany s. 29.

Fascykuty s. 30-35.

37. Spis ksiażek, pamiatek narodowych i osobliwości [z księgozbioru Piotra Umińskiego $w$ Warszawie].

634 Pol. [poł. XIX w.]. 20.5 x 13.5 cm. K. 97. Opr. płpł.

Spis zawiera:

K. 1-6v. A. Historia Polska i Powszechna nr 1-180.

K. 21-21v. B. Jeografia i karty jeograficzne nr 1-47.

K. 23-27v. C. Dziela naukowe nr 1-137.

K. 35-36 D. Poezye i powieści nr 1-69.

K. 53-55. E. Katalogi, stowniki, kalendarze i czasopisma nr 1-80.

K. 57. F. Akta i broszury wolnomularskie nr 1-2.

K. 61-67v. G. Zabytki starożytmości i pamiątki nr 1-218.

K. 73-73v. H. Medale i numizmaty nr 1-13.

K. 76-77. I. Godla wolnomularskie nr 1-39.

K. 82. K. Obrazy, ryciny i szkice nr 1-127.

K. 90-92. L. Fotografie nr 1-294. 
38. Wykaz ksiqżek starych znayduiqcych sie przy klasztorze PP. Bernardynek $w$ Stonimu.

882 Pol., około poł. XIX w. $20 \times 17 \mathrm{~cm}$. Poszyt. S. zapis. $41+2 \mathrm{k}$. ochr. +13 niezapis. 13 .

Inwentarz zawiera listę $258 \mathrm{książek,} \mathrm{z}$ tego 215 starych druków, 2 rękopisy z XV wieku, 3 inkunabuły oraz 48 druków z XIX w. Na końcu notatka: Oprócz wspomnianych tu ksiażek, nie przejrzanych: kolo 100 ksiażek polskich i koło 100 lacinskich z wieku XVIII, tudzież b. dużo modlitewników, brewiarzy, mszalów oraz rękopism.

39. Biblioteka Numizmatyczna [dziet od] A-F Towarzystwa Numizmatycznego w Krakowie.

1725 Rjęz. Koniec XIX/pocz. XX w. Katalog kartkowy. Pudło.

W wykazie znajdują się stare druki XVI-XVIII w. oraz dzieła do końca lat 20. XX. Według informacji na kartce biblioteka Towarzystwa Numizmatycznego liczyła 1825 tytułów w siedmiu szafach oraz 132 rękopisy. Kartoteka trafiła do Muzeum Narodowego wraz z dokumentami po Towarzystwie Numizmatycznym.

40. Katalog Biblioteki Teatralnej nieznanego z nazwy teatru $w$ Warszawie.

1665 Pol. Koniec XIX w. 20.5 x 16.5 cm. K. zapis. 20. Opr. płpł. Katalog ułożony chronologicznie i alfabetycznie $\mathrm{z}$ informacją o nazwisku autora, roku wydania i topografii. Zawiera 3 dzieła z XVII wieku, 130 dzieł z XVIII wieku (komedie polskie, francuskie), 3 dramaty włoskie z XVIII wieku, 33 opery $z$ lat 1759-1791, 5 utworów poetyckich $z$ lat 1740-1793, 162 dzieła komediowe z XIX wieku.

41. Katalog dziet numizmatycznych znajdujacych się w „, Bibliotece Horodeckiej" Antoniego Urbanowskiego pisany przez NN osobę

973 d Rjęz. 1903. 22 x 18 cm. Poszyt. S. 16. Bez opr.

Zawiera 66 tytułów dzieł numizmatycznych w 120 woluminach od XVII do XIX wieku biblioteki zbieracza książek, numizmatów i obrazów Antoniego Urbanowskiego w Horodźcu, z której korzystał niegdyś Józef I. Kraszewski.

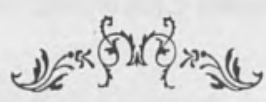


Przypisy:

'Pagaczewski J., Muzeum Narodowe w 20-ta rocznice otwarcia 1909 r., Kraków 1909; Szukiewicz M., Rozwój i przyszłość Muzeum Narodowego w Krakowie, Kraków 1909; Dobrowolski T., Zarys historii Muzeum Narodowego w Krakowie , Sprawozdania i rozprawy Muzeum Narodowego w Krakowie" R. 1951, Kraków 1952 s. 12-45; Kopff A., Muzeum Narodowe w Krakowie. Historia i zbiory. Kraków 1962; Kocójowa M., Pamiatkom ocalonym z burzy dziejowej. Muzeum im. Emeryka Hutten-Czapskiego, Kraków 1978.

${ }^{2}$ Tomaszewicz J., Katalog dokumentów pergaminowych Muzeum Narodowego w Krakowie, Kraków 1991.

${ }^{3}$ Zbiory rękopisów w bibliotekach i muzeach $w$ Polsce. Przewodnik. Oprac. D. Kamolowa przy współudziale K. Muszyńskiej, Warszawa 1988, s. 131-139

${ }^{4}$ Różycki E., Inwentarze rękopismienne bibliotek oraz inne materialy dotyczqce polskiej ksiqzki na kresach dawnej Rzeczypospolitej, „Roczniki biblioteczne” 1995 z. 1-2, s. 143-149; Tenże, Materialy źródłowe do dziejów polskiej ksiqzżki w archiwach i bibliotekach Lwowa, Kijowa, Mińska i Wilna, „Roczniki biblioteczne” R. XXXI, 1987 z. 2, s. 305-317 $\mathrm{i}$ in. prace tego autora.

${ }^{5}$ Migoń K., Uwagi o rozwoju i perspektywach historiografii ksiażki, „Studia o książce" T. 5, 1975 s. 33; Problematyka źródloznawcza w bibliologii, ,Studia o ksiqżce” T. 15, 1985 s. 3-17 i in. artykuły w tym tomie; Bieńkowska B., Kilka uwag i propozycji w sprawie badań księgozbiorów historycznych, ,Studia o ksiqżce” T. 16, 1986, por. artykuły dotyczące tematu w: „Studia o ksiqżce" T. 17, 1988.

${ }^{6}$ Sesja naukowa w Jodłowym Dworze w XII 1983 roku i w Bartkowej k. Nowego Sącza 21-24 XI 1984 roku.

${ }^{7}$ Z Badań nad Polskimi Ksieggozbiorami Historycznymi, pod red. B. Bieńkowskiej i J. Wojakowskiego, t. 1-16, Warszawa 1975-1995.

${ }^{8}$ Straty bibliotek w czasie II wojny światowej w granicach Polski z 1945 roku, Warszawa 1994. Cz. I-III.

9 Staniszewski Z., Imwentarze biblioteczne wieku XVII i XVIII w rękopisach Ossolineum, "Ze skarbca kultury" Z. 7, 1955 s. 192-214; Jabłońska W., Inwentarze i katalogi biblioteczne w zbiorach rękopiśmiennych Biblioteki Zakladu Narodowego im. Ossolińskich, "Ze skarbca kultury” Z. 20, 1969 s. 73-179; Bolewska D., Marciniak R., Katalogi i inwentarze ksiq̨żek w zbiorach rękopiśmiennych Biblioteki Kórnickiej, cz. I. Katalogi i inwentarze do r. 1800. „Pamiętnik Biblioteki Kórnickiej” 1987, z. 22 s. 157-172

${ }^{10}$ Partyka J., Rękopisy dworu szlacheckiego doby staropolskiej, Warszawa 1995, s. 22-47, tamże bibliografia.

"Testamenty szlachty krakowskiej XVII-XVIII w. Oprac. A. Falniowska-Gradowska. Kraków 1997, Rozprawy Wydziahu Hist.-Filozof. Polskiej Akademii Umiejętności T. 86.

${ }^{12}$ Chamerska H., Akta hipoteczne i notarialne jako źródlo do badań nad ksiegozbiorami prywatnymi XIX i XX wieku, [w:] Z Badań Nad Polskimi Księgozbiorami Historycznymi. Pod red. B. Bieńkowskiej, z. 3, 1977 s. 3-22.

${ }^{13}$ Bieńkowska B., Inwentarze księgozbiorów prywatnych jako żródlo do badan nad dziejami czytelnictwa, „Studia o książce” T. 18, 1989 s. 65-74.

${ }^{14}$ Peleszowa S., Archiwum Mlynowskie Chodkiewiczów 1499-1932, Archeion T. LXIX, 1979 s. 115, 117, 119. 